Przegląd Badań Edukacyjnych Educational Studies Review

ISSN 1895-4308

nr 28 (1/2019), s. 95-110

\title{
On the Need to Strengthen Social Capital in Pro-Inclusive Education and Supporting People with Disabilities
}

http://dx.doi.org/10.12775/PBE.2019.006

\begin{abstract}
In the article, I point out the weaknesses in the domestic social capital and at the same time I emphasize its key role in creating pro-inclusive actions and solutions for people with disabilities in all spheres or areas of their life activities. However, the subject of my special reflection is the education system and the need to strengthen capital resources and social trust in its space. It is the basis for the inclusion and support of these people and their families in the cooperation with the local environment. It creates a climate for practicing civic skills; readiness of all entities/participants of education for a mutual, based on trust and respect cooperation that is open to the possibility of including others to a different extent and whom are not only formally involved in their education.
\end{abstract}

Key words: social capital, people with disabilities, pro-inclusive education, strengthening social capital at school

\section{Introduction}

Severely experienced by most citizens - nondisabled and those with disabilities - market fundamentalism, being an inseparable part of the neoliberal politics and economy carried out in Poland, impedes the creation of pro-inclusive activities and solutions in both the social sphere and the system of education. The 
consumerism cult clearly restricts the domestic social capital whose historically formed configuration, above all, is characterized by strong connections between individuals and groups deriving from the same environments (bonding ties unifying and reinforcing homogenous groups). At the same time, there occurs the weakening of social trust towards institutions as well as reciprocal relationships between people from formal and informal groups, thus, there are weak bridging ties connecting heterogeneous groups (Sowa, 2008, 2015; Działek, 2011, Węziak-Białowolska, 2010, Mikiewicz, 2014). Therefore, the feeling of social solidarity as well as the civil engagement in the common welfare creation process is rather low. The relationships are usually limited to strong emotional bonds and contacts with family, friends or neighbours, somehow 'blocking off' the relationships and cooperation with others which are known to stimulate the development and enhance the change of one's life situation. As Janusz Czapiński (2015) emphasizes, social capital, apart from influencing the economic development of a country, has a considerable significance for integration and social solidarity. It further counteracts exclusion and discrimination, serves to complete and help out inefficient institutions of a country, controls the governmental sector (including the commercial one as well) and enforces the country's responsibility towards its citizens. The indicator of social capital, in my view being particularly significant for the completion of diverse needs and expectations in the area of social inclusion and the support of children, teenagers and adults with disabilities or with special needs, is the generalized interpersonal trust. Unfortunately, in this aspect we are located in one of the last places among countries included in the European Social Survey. Meanwhile, high generalized trust inspires voluntary activities for the benefit of local community, including wage-free work for those in need (voluntary work), active participation in elections and work for public or social benefit institutions (associations, foundations, clubs) as well as a positive, accepting attitude towards others including people with disabilities. Unfortunately, social capital stands at a low level in our country. Therefore, if high level of social capital determines the nature of civil society capable of joint development in a more and more competitive market environment (Czapiński, 2015), thus, in such a situation - of social atomization of individuals and groups - the perspectives or the chances for organizing a highly dynamic, elastic and pro-inclusive support system for people with disabilities are rather unsatisfactory. Therefore, it is necessary to intensify activities for the creation of social bonding networks effectively including these people in the social life, in a way enabling cooperation with others - the nondisabled, for the common welfare of the whole society (Czapiński, 2015). 
The synergy effect, enhanced by both team work and cooperation between nondisabled people and people with disabilities, based on positive interactions, proper division/share of duties taking into account possibilities and limitations or interests, shall create their real (not mock) social integration and inclusion in the area of the system of education. The organization of personalized and proinclusive support for people with disabilities, considering and appreciative, as Eugenia Potulicka (2012) notices, 'possibilities to help oneself' - empowering these people, their families and local communities by combing the individual responsibility, social support and the country's activities, is definetely not a simple task (cf. Potulicka, 2012). It further obliges to reflect on and eliminate or at least limit these obstacles and weaknesses which in the system of education make them problematic. Referring to the idea put forward by Robert D. Putnam (2008), stating that among social groups deserving special attention with relation to the shaping of social capital, pupils and schools ought to be mentioned in the first place. I shall add here that other subjects engage themselves to a varying degree in the process of domestic education as well. The knowledge on public issues (including problems experienced by people with disabilities) and the everyday implementation of civil skills are the initial conditions for effective participation and readiness of every participant of education to undertake assistance activities for the benefit of others, including people with disabilities (cf. Potulicka, 2012). Indicating the significance of the matter for inclusion and launch of assistance activities for the highly diverse in their expectations and needs group of people, further in the article I shall also refer to another issue, in my view not less important for the creation of social capital, namely - the underestimation of capabilities of parents and families of people with disabilities. Undoubtedly, the family environment of pupils/people with disabilities and the quality of the relationship with the school, create the space for reciprocal cooperation based on trust and respect, open to the possibility of including other subjects not only those officially engaged in their education.

\section{Shortcomings in the social trust as an obstacle for inclusion and support of people with disabilities in the system of education}

Regardless of whether social capital is viewed as an individual (Bourdieu, Camelon) or a public benefit (Putnam, Fukuyama, Sztompka, Czapiński), its basic element is trust (Potulicka, 2012) being the ground for 'relationships and bonds at the level of both direct relationship among people as well as social macrostructure $[\ldots]$ favouring the reduction of uncertainty and risk' (Domański, 2014, 
p. 8). Measurable benefits deriving from high trust are noticed in the economic, political and everyday contacts spheres. Greater trust reduces e.g. 'transaction costs' - it shortens negotiation time, facilitates the parties agreement, stimulates the performance and entrepreneurship of entities. In the political sphere, it favours the reinforcement of the stability of the social system as well as the legitimatization of the ruling class. However, at the level of everyday contacts, it provides people with the feeling of confidence deriving from the belief that they are a part of a firm social structure. Trust provides the feeling of comfort, which is reflected in the results of research indicating the appearance of strong dependence between the level of trust and the life satisfaction and also the feeling of happiness. The belief that others shall not let us down is built into being a part of a community and closeness to other people (Domański, 2014, p. 10). Meanwhile, as shown by the abovementioned ESS research (2014, 2016), Poland in respect of the level of generalized trust is located in one of the last places, although the lowering level of interpersonal trust shall be regarded as particularly unfavorable, which may indicate the rising feeling of social uncertainty, a process said to have begun after 2010 (Rychard, 2016). For reference, the highest level of social trust is noticed in Scandinavian countries, which can be explained by these countries' way of functioning, based on the model of a friendly, protective country, but also by possessing some qualities favouring development of e.g. civil activity seen in the participation in various social organizations, low inequalities in income ( the lowest in Gini coefficient), the conviction of the chances for equality as well as high legitimization of politicians and government (Delhey and Newton 2005, Domański, 2014). Lower social stratification in these countries weakens social barriers and improves communication among people from different classes, strata or professional groups. The lack of such communication, as Henryk Domański emphasizes, 'not only impedes the breaking of mutual prejudice, stereotypes and ignorance barriers creating distrust, but it also reduces direct relationships, replacing them with those more formalized («official»), reinforcing the feeling of alienness' (Domański, 2014, p. 14).

In this context it seems optimal to create or activate, in the social space and in the system of education, such forms of organization, activities or initiatives mostly of bridging nature, which by incorporating the representatives of various backgrounds, including children, teenagers and adults with disabilities, by referring to universal values, shall favour the vanishing of social distance, have a bonding effect, create the atmosphere of 'inclusive' trust and support. (cf. Działek 2011). 
As the research by Kamil Hernik, Marek Solon-Lipiński and Jędrzej Stasiowski (2012) indicates, a considerable significance for this interpretation of the development of social capital - being in my view a favourable ground for inclusion and the creation of support network for students with disabilities in the course of education (perceived as a lifetime process) - without a doubt, is found in the institutional surrounding of schools, which cooperates with them to a varying degree and range in the local environment. A model approach has been adopted to view such cooperation, having carried out an empirical ${ }^{1}$ data analysis. The following types of cooperation have been distinguished; local, beyond-local, thematic, incidental and symbiotic. Nevertheless, the suggested types, as the authors indicate, do not exhaust the complexity of the reality in which schools function, but they allow us to point to the basic problems connected with the building and using of their social capital. The main prerequisite for these types of distinction was to indicate some characteristic traits, which decided about the specificity of the use of social capital built on the ground of a particular cooperation model. Leaving out the detailed analysis of the distinguished types, it is worth noting that within each of them; schools may develop their institutional resources of social capital, comprising more or less permanent relationships with the partners of the cooperation. The binder of such relationships is reciprocal trust found not only in the personal relationships among the institutions employees, but also in the institutionalized norms of cooperation, which have their source in legal regulations and former cooperation experiences (Hernik, SolonLipiński, Stasiowski, 2012, p. 9). The resources of social capital anchored in the networks of cooperation between schools and the local environment, facilitate the development of the schools' didactic potential by being the source of material and financial support. They further allow them to create attractive, stimulating and pro-inclusive environment for children, teenagers and adults with disabilities or with special needs. However, it is worth noting, referring to the quoted authors, that 'by the participation in the same cooperation networks, pupils are being instrumentally used as a public relations resource of local politicians, and

${ }^{1}$ While analyzing the empirical data concerning the cooperation between school and environment, the authors took into account 'numerous factors e.g. the type of a partner and its location, the frequency of contacts (made once or periodically), the contacts' form (official, informal) the essence (the type of exchanged resources and their direction), the intensity as well as the evaluation of the cooperation, the grounds (voluntary vs. obligatory) as well as the context of the beginning of the cooperation. In practice, it turned out that not each of the abovementioned and analyzed dimensions allowed for building interesting and accurately describing reality distinctions' (Hernik, Solon-Lipiński, Stasiowski 2012, p. 6). 
the school loses its worldview neutrality by engaging in the Church's catechetic mission' (Hernik, Solon-Lipiński, Stasiowski, 2012, p. 9). However, informal cooperation between schools and social control institutions - police and social assistance has been observed, which might have violated the privacy of pupils and their parents. This example, together with other weaknesses noticeable in schools' functioning with respect to their cooperation with the so called external environment, are perceived as threatening to the development of their social capital, should be eliminated or at least limited. The awareness of obstacles or threats will enable schools to create optimal educational policy in cooperation and with a reciprocal support provided by numerous institutions in local environment and the pupils' parents, including parents/caretakers of students with disabilities (Hernik, Solon-Lipiński, Stasiowski, 2012).

\section{Families of pupils/ people with disabilities and their relationships with school as a space to build reciprocal social capital and support.}

Pupils' families and their relationships with school are as important as the local environment in the process of building social capital; their own and the school's. Pupils, regardless of the stage of education, do not function in two distinct communities after all, but in both simultaneously being their full members and the subjects of influence at the same time. (Malinowska, 2016). The reciprocal relationships between all pupils' families and school - often being the centre of life of the local community, decide on the level of the use of the school's potential or its resources in the creation of the available and diverse pro-inclusive network of support for them. Therefore, schools ought to foster the creation of trust, inter - human communication culture, empathy and the feeling of responsibility which shall not occur in relationships of insincerity, pretending or lack of bonds between the school management and the educational process as well as students and their parents. (Śliwerski, 2015, p. 610). Meanwhile, as Aleksander Nalaskowski (2007) stated over a decade ago, the school still lacks educational community or any community at all, which could provide the grounds for a dialogue and the building of social capital ${ }^{2}$. Thus, there does not exist

${ }^{2}$ Collective longitudinal studies, having the greatest diagnostic value on the role of school and academic education in the development of social capital of the new, post-socialist generation of young Poles being the first class of junior high school graduates, were carried out by Maria Dudzikowa in Poland (Śliwerski, 2015, p. 165) 
a good ground for the development of the support network for pupils with disabilities and their parents. It seems, though, that an interesting alternative for a school functioning in this way, may be, as Józef Kuźma (2013) suggests, the school's quality transformation, thus 'a new school in terms of quality - open to changes, supporting the children development, however, much more costly. It will be an institution creating better conditions, more demanding, and children - friendly at the same time' (Kuźma, 2013, p. 16). I shall add 'friendly', because it is perceived in the categories of public welfare, open to the pupils' special education needs, abilities and interests. Therefore, comprehensively supportive for both children/students and their families in each possible dimension; psycho-emotional, social, service, custodial, educational and finally rehabilitative (Maciarz, 1993). It is a school which is not being treated by its governing bodies in the category of costs, but as an investment, including the development of social trust in cooperation with the local environment.

The reactivation of trust enabling the educational dialogue being the ground for the building of social capital and support network, should be taking place at a few levels of relationship; pupil-pupil, pupil-teacher, pupil-parent, teacher-parent, parent-parent, school-local environment (Malinowska, 2016, cf. Mendel, 2013). As Joanna Malinowska (2016, p. 285) states 'only then will it be possible to exchange the cultural knowledge, make contacts, gain social resources understood as key/life skills' and cross closed bonds de facto isolating and excluding students with disabilities and their families from the local community. It means that the structural grounds for the bonds opening to the surrounding reality is the mutual merging of different environments; the pupils', the teachers' the parents' and the locals'. The bridging bonds in question create pro-inclusive trust and support, eliminate stereotypes, reluctance or social distance among every education subjects. Accordingly, I mean a school of cooperation, teaching civil activity. A national project run in the years 2013-2015 - A school of cooperation. Pupils and parents as social capital in a modern school may serve as an example of such an activity. The project's main aim was to reinforce the emphasized in its title cooperation between pupils, parents, teachers and representatives of local environments, taking place in kindergartens and schools in Poland. The priority of the project was to inspire the school environment to implement good practices in the context of reciprocal cooperation as well as introduce permanent changes in the perception of the role of pupils and their parents in the school activities. It is worth expanding, showing the specific objectives as well, which were logically systematized and reflected in the following activities carried out respectively: 
1. Diagnosing both the contemporary cooperation in schools (the project included state kindergartens, primary schools, junior high schools and high schools) and the expectations of parents, pupils and teachers/principals in the matter;

2. Developing cooperation models adequate to Polish conditions and solutions aiming at reinforcing the cooperation in question at every educational stage (not excluding kindergartens);

3. Reinforcing cooperation in over 1200 schools by the participation of every indicated subject in trainings and workshops; the project participants (6600 people - parents, teachers/principals and pupils) organized in their schools debates on the condition of cooperation between them and the ways of its reinforcement. Afterwards, they planned and executed joint ventures engaging these three communities. It is worth noting that in order to preserve the positive changes occurring at schools, 700 two-year school programmes for active cooperation (SPAW) were prepared, which, as the organizers - The Ministry of Education together with the Local Democracy Development Foundation, ensured, were to be implemented following the project completion.

4. Developing and sharing the knowledge/information base concerning the possibilities of the parents' active participation or their activities in schools and kindergartens;

5. Developing and sharing knowledge/ information resources concerning active participation of pupils in the school life, with a particular consideration drawn to the possibilities of undertaking such an activity in the pupils' councils. (http://szkolawspolpracy.pl/o-projekcie/ [DOA:12.07.2018]).

Leaving out further, more detailed analyses of the assumptions and the results of the project, which have been posted on the previously mentioned webpage, I shall focus on a few obtained results from the carried out activities and research (quantitative and qualitative), which are particularly significant for the issues addressed by me. Thus, a vast majority of parents evaluate the school activities (the atmosphere at school, the educational activity, the parents' contact with the teachers and the principals' activities) as good and rather good (given the lack of the 'very good' category). The majority expressed the opinion on the need of their participation in the evaluation of teachers performance; such a view was expressed more often by parents having a university degree. Moreover, two thirds of people involved in the research admitted that in the process of school education, the creation of conditions for independence and 
development is of great significance (which was positively connected with the level of declared trust to others). Parents with low monthly income expected the emphasis to be put on discipline and order. What's important, the research participants declared the acquaintance with the parents' and the children's rights, however, they 'used' these rights mostly in situations of inadequate behaviors of pupils noticed in their contacts with their peers (e.g. fights, conflicts, inappropriate treatment and disagreements between children and teachers). In this case, the possible high level of superficiality of these declarations has been noted. Another example is the evaluation of engagement in school life; the reasons for the lack of such engagement were: lack of time and, what is important, the assumption that every activity undertaken by schools should be carried out by their employees. Most parents did not have a feeling of having an influence on the school activities. It has also been determined that in many schools there did not exist any effective mechanisms of cooperation between the school pupils' councils and the representatives of parents, what is more, in the principals assessment only in one third of schools, pupils had a real influence on the use of funds from the parents' council. Thus, the scope of power assigned to school pupils was quite often limited or the power was of illusory nature. The considerable role of teachers and the principal in the creation of the cooperation environment process has also been stressed out. The school management style has also turned out to play a significant role. If the style had been of traditional nature, the relationships developed a hierarchical character, they had the nature of dependence and subjection, there appeared a distance between the principal and the teaching staff. The latter did not play an important role in initiating activities, what is more, teachers were often excluded from the decision making process concerning fundamental issues for the school functioning etc. In consequence, initiatives pursuing consolidation of all the environments, including the local one as well as those aiming at narrowing the cooperation between them, were missing. Obviously, there were schools in which both the management and teachers were open to a dialogue, cooperation, innovation. They strove for the development of independence and self-government of pupils as well as inspired parents' activities offering them the role of equal participants of the school community. There was a good atmosphere for cooperation, implementation of democratic management mechanisms based on joint action, delegation of part of authority, sharing duties and responsibility. The priority was to build reciprocal trust, partnership, the feeling of unity and shared responsibility for the school. (http://szkolawspolpracy.pl/2015/attachments/article/13/2_Raport\%20 upowszechniaj\%C4\%85cy.pdf [DOA: 12.07.2018]). 
I wish there were more such schools effectively building social capital and support for the pupils and their parents. Within the project some remedial actions have been initiated and proposals for cooperation models between institutions and parents and the local environment have been developed (http:// szkolawspolpracy.pl/2015/attachments/article/13/7_Prezentacja\%20o\%20 modelach $\% 20$ wsp $\%$ C3\%B3\%C5\%82pracy_dr\%20Olga\%20Napiontek.pdf [DOA: 12.07.2018]).

The mentioned, although only a few chosen, results of the research carried out within the project $A$ school of cooperation. Students and parents as social capital in a modern school, lead to two more afterthoughts. I connect them with the necessity to view school as a learning organization as well as the need to verify current training of educators/teachers by initiating a positive selection of candidates for the profession as well as granting a higher rank to practical education as it favours the development of soft skills in high school graduates.

Dynamic civilizational, economic and social changes faced by contemporary school assign new duties and requirements if the school wants to be competitive against a vast offer from the Internet, TV and other mass media. School functioning as the source of information for pupils and a place where teachers transfer the information is no longer justified. (Senge et al. 2002). As rightly, almost two decades ago, Senge et al. emphasized 'in the coming years, pupils will not have any reason to enter the school building to get information. Nevertheless, they will have to go there to acquire some basic skills, including the ability to evaluate processes and cooperation while learning - thus, to learn how to consolidate the knowledge, reflect on it and put it into practice' (Senge et al. 2002, p. 566). Therefore, the transformation of school is necessary and expected, it should amongst other things focus on the relationship between the subjects of education, particularly those between the teachers and the pupils. Nevertheless, the former, by acquiring the ways of thinking and acting arising from experiences gained from the environments and institutions in which they were functioning while their personalities were being shaped, quite often bring those experiences to schools, which become their workplaces later in life. Such teachers have a feeling of exclusiveness to set goals and tasks for the pupil to obey; the pupil learns that he has achieved a success only when the teacher informs him or her about that. Children/pupils quite quickly find out what to do in order to achieve good results in learning and to satisfy the teachers. This knowledge is being brought to the professional career ground, including the teacher profession, in which, as adults, such people are able to effectively satisfy their superiors, however they are unable to improve the system of education, increase 
the quality of cooperation with children, their parents and the local environment (cf. Senge et al., 2002). They are not 'social capitalists'- people who are open and who create bonds, reinforce them and improve their range and strength (cf. Kwieciński, 2012). They are people who do not engage in the creation of social capital of school, which is the ground for the support of pupils with special education needs. That is why, there is a need for a constant dialogue and discussion among every subject of education, thus, 'the exchange of opinions, confrontation, sharing doubts, posing and solving problems, sharing experiences, receiving feedback, comparing, receiving advice, looking for confirmation (denial) of one's views, discussing professional topics freely, sharing one's own practical solutions, analysing both successes and failures' (Fura, 2007, p. 218).

Undoubtedly, the abovementioned skills ought to be learnt by contemporary teachers, whose identity is at present threatened by the far too frequently appearing feeling of alienness from the professional group and discomfort caused by the low social status of the performed job. Reluctance to identify oneself with one's own professional group far too often results in the lack of openness for cooperation with the teaching staff of one's school; teachers hardly ever identify with their school's objectives, treating them as imposed on them, they do not have a feeling of influence on the objectives setting or their realization. Therefore, they create a group of socially atomized individuals more open to relationships with colleagues from other schools instead of those who work with them (cf. Kwiatkowska, 2005; Żytko, 2015). Moreover, the absence of feeling of being in control and the possibility of participation in creating the system of education 'lead to the acceptance of the fact that the existing situation is unchangeable. Therefore, they lock themselves in local, school, classroom activities far from noticing a wider socio-cultural perspective. They do not undertake ambitious actions, independent initiatives since they fear failure. All these arouse frustration and fear of responsibility, but also reluctance to introduce changes' (Żytko, 2015, p. 2). Hence, the priority in the process of contemporary teachers' education is the development of their skills and shaping attitudes, which favour building at school a community of teachers, pupils, parents and local people in order to achieve good quality education and provide support for every child/pupil. Such skills and attitudes favor mobilization to act, release reciprocal, creative, unhampered and enterprising activity of educators/teachers. They additionally reinforce bonds among people within the same professional group, favor mutual help and readiness to support and work for the benefit of others (cf. Sztompka, 2005). 'By building social capital of teachers at school, we build social capital of pupils/citizens-to-be in their adulthood' (Wiktorzak, 2009, p. 261). 
The quality of relationship among pupils in a group/classroom creates each pupil's resources, but equally it creates the resources of the group as a whole and the resources of the school the group is part of. At the same time, there occurs a reciprocal exchange of the resources of social capital; the social capital conveyed from the school to the pupils creates the conditions for the group activity, being the consequences of relationships observed between them and possibilities created in the context by the school (Bochno, 2016).

A solution might be programme suggestions which develop such competences in students of teacher training universities e.g workshops practically teaching cooperation with parents, enabling to indicate particularly significant for both parties difficulties they experience in relationship with the school and the children, by means of a dialogue and discussion. (Żytko, 2015). Additionally, a good quality of teaching practice during studies shall favor the development of skills and competences of students connected with proper division and assignment of tasks to pupils (adequate to their preferences and resources), using 'collective wisdom' of a team/group or a class with simultaneous openness to diverse views of pupils, making use of the best developed solutions, avoiding mistakes by sharing experiences, providing assistance or support to those pupils (their parents as well) who need it at a certain point of time or while performing a given task (applying the power of peer tutoring ${ }^{3}$ ) (cf. Elsner 2015). Another, valuable form supporting the development of substantive and social competences of employed teachers as well as principals is e.g. mentoring. Its essence is appreciating and using the richness of knowledge and experiences of educators having many years of well-assessed pedagogical work, those who often engage in the support process of pupils with disabilities and their parents (families) at school and in the local environment.

\section{Final afterthoughts}

The system of domestic education, being in crisis for a while and therefore requiring a thorough reorganization, has become my concern in connection with a justified in the content of the article necessity to reinforce, within its space, social capital which is, what I wish to emphasize, the ground for the creation of personalized network of support for pupils/people with disabilities and their families in view of the spread of social and educational inclusion. Social or en-

3 The advantages of peer tutoring with reference to pupils with intellectual disabilities have been interestingly discussed by Anna Zamkowska (2009) in her monograph. 
vironmental context of schools functioning together with cultural and economic factors are considerably significant for their organization and for the undertaken tasks, which should focus on the process of shaping aware, creative and responsible citizens prepared to cooperate while fulfilling social roles, tolerant and open to the needs of others. In this process, acquiring and gathering knowledge shall give way to the development of the ability to search for knowledge, select it and reflect on it as well as to acquire competences essential to start a relationship and solve problems jointly (Juszczyk-Rygałło, 2017). Therefore, one 'should undertake any action open to the creation of social bonds, which may result in educating young people in the spirit of trust, unity, joint responsibility and creative cooperation. The most productive economic and social approach is said to be the concept of building non-material resource which is social capital of school' (Juszczyk-Rygałło, 2017, p. 54). However, it needs to be concluded that such capital creation 'requires both financial investments to e.g. reduce the number of pupils in each class, reorganize the school space to match diverse needs of teachers and pupils as well as release their various spontaneous behaviours, provide more extracurricular activities, appoint the tutors of science circles, pupils organizations, associations etc. What is more, it requires substantial amount of time and effort. I mean long standing interactions, contacts and meetings which build traditions and the school atmosphere based on informal bonds (Dudzikowa 2009, p. 21).

It obliges all subjects of education - teachers/principals, pupils, parents and the representatives of the local environment to implement joint actions equally beneficial for children, teenagers and adults with disabilities. Therefore, in the content of the article, by emphasizing the significance of trust or social capital for the creation of inclusive and assistance activities for the diverse group of people, I indicted the considerable significance of parents and families of such people as well as the quality of their relationship with school.

\section{References}

Bochno, E. (2016). Rola zespołowości uczniów. Dyrektor Szkoły. Miesięcznik Kierowniczej Kadry Oświatowej, 5(269), pp. 76-78.

Czapiński, J. (2015). Stan społeczeństwa obywatelskiego. In: J. Czapiński, T. Panek (eds.), Diagnoza Społeczna. Warunki i jakość życia Polaków. Raport (pp. 332-372). Warszawa: Rada Monitoringu Społecznego.

Dudzikowa, M. (2009). Stan i szanse rozwoju kapitału społecznego w środowisku szkolnym, Retrived 14, July 2018, from: http://rep.up.krakow.pl/xmlui/bitstream/handle/1171- 
6/1614/02--Stan-i-szanse-rozwoju-kapitalu-spolecznego--Dudzikowa.pdf?sequence$=1 \&$ isAllowed $=\mathrm{y}$.

Domański, H. (2014). Zaufanie między ludźmi. Res Humana, 6(133), pp. 11-16.

Działek, J. (2011). Kapitał społeczny - ujęcia teoretyczne i praktyka badawcza. Studia Regionalne i Lokalne, 3(45), pp. 100-118.

Elsner, D. (2015). Nowo powołany dyrektor szkoły. Zadania i wyzwania. Projekt „Program wzmocnienia efektywności systemu nadzoru pedagogicznego i oceny jakości pracy szkoły etap 2", realizowanego przez Ministerstwo Edukacji Narodowej w ramach III Priorytetu Programu Operacyjnego Kapitał Ludzki, Działanie 3.1 współfinansowane z Europejskiego Funduszu Społecznego, Retrived July 12, 2018 from https://www. npseo.pl/data/documents/1/68/68.pdf.

Fura, B. (2007). Szkoła jako ucząca się organizacja. Annales Universitatis Mariae Curie-Skłodowska. Sectio H, Oeconomia, 41, pp. 215-227.

Hernik, K., Solon-Lipiński, M., Stasiowski, J. (2012). Kapitał społeczny szkoły. Budowanie i wykorzystywanie. Polityka Społeczna, 1, pp. 5-9.

Juszczyk-Rygałło, J. (2017). Kształtowanie kapitału społecznego szkoły w warunkach wielokulturowości. Teraźniejszość - Człowiek-Edukacja, t. 20, 2(78), pp. 53-66.

Kwiatkowska, H. (2005). Tożsamość nauczycieli. Między anomiq a autonomią. Gdańsk: Gdańskie Wydawnictwo Psychologiczne.

Kwieciński, Z. (2012). Dlaczego ludzie niszczą więzi społeczne - tropy neuroewolucyjne. Studia Edukacyjne, 22, pp. 49-53.

Kuźma, J. (2013). Nauka o szkole. Teorie i wizje przyszłej szkoły. Roczniki Pedagogiczne, t. 5, 2(41), pp. 15-52.

Maciarz, A. (1993). Wspomaganie rodziny w wypełnianiu podmiotowej roli w wychowaniu i rehabilitacji dzieci. In: R. Kostecki, A. Maciarz (eds.), Podmiotowa rola rodziców w rehabilitacji dzieci niepetnosprawnych (pp. 35-37). Zielona Góra: Wydawnictwo Uczelniane WSP.

Malinowska, J. (2016). Rodzina i szkoła jako przestrzenie budowania kapitału społecznego. Wychowanie w Rodzinie, t. 13, 1, pp. 279-292. Retrived July 12, 2018 from: http:// repozytorium.uni.wroc.pl/Content/78377/Rodzina_i_szkola_jako_przestrzenie_budowania_kapitalu_spolecznego.pdf.

Mendel, M. (2013). Rodzice też chodzą do szkoły: społeczna rola rodziców w systemie edukacji. Refleksje, 1, pp. 8-12. 
Mikiewicz, P. (2014). Kapitat społeczny i edukacja. Warszawa: Wydawnictwo Naukowe PWN.

Nalaskowski, A. (2005). Dzikość - ucieczka od ufności? In: J. Danilewska (ed.), Fundamenty edukacyjnej wspólnoty (pp. 81-90). Kraków: Wydawnictwo Uniwersytetu Jagiellońskiego.

Potulicka, E. (2012). Kształtowanie kapitału społecznego w szkole - wprowadzenie do problemu. Studia Edukacyjne, 22, pp. 97-107.

Putnam, R. (2008). Samotna gra w kręgle. Warszawa: Wydawnictwo Akademickie i Profesjonalne.

Rychard, A. (2016). Czy nowy kryzys legitymizacji i stary deficyt zaufania? Wstępne refleksje i empiryczne ilustracje. In: P.B. Sztabiński (ed.), Polska-Europa. Wyniki Europejskiego Sondażu Spolecznego 2002-2015 (pp. 10-16). Warszawa: Wydawnictwo Instytutu Filozofii i Socjologii PAN.

Senge, P., Kleiner, A., Roberts, Ch., Ross, R.B., Smith, B.J. (2002). Piata dyscyplina. Materiały dla praktyka. Jak budować organizację uczaca się. Kraków: Oficyna Ekonomiczna.

Sowa, J. (2008). Ciesz się, późny wnuku! Kolonializm, globalizacja i demokracja radykalna. Kraków: Korporacja Ha!art, Retrived July 12, 2018 from: http://otworzksiazke.pl/images/ksiazki/ciesz_sie_pozny_wnuku/ciesz_sie_pozny_wnuku.pdf.

Sowa, J. (2015). Inna Rzeczpospolita jest możliwa! Widma przeszłości, wizje przyszłości. Warszawa: Wydawnictwo W.A.B.

Śliwerski, B. (2015). Edukacja (w) polityce. Polityka (w) edukacji. Inspiracje do badań polityki oświatowej. Kraków: Oficyna Wydawnicza Impuls.

Szkoła współpracy. Uczniowie i rodzice kapitałem społecznym nowoczesnej szkoły. Retrived 12, July 2018 from: http://szkolawspolpracy.pl/.

Sztompka, P. (2005). Zaufanie, nieufność i dwa paradoksy demokracji. In: P. Sztompka, M. Kucia (eds.), Socjologia. Lektury (pp. 397-408). Kraków: Znak.

Węziak-Białowolska, D. (2010). Kapitał społeczny w Polsce - propozycja pomiaru i wyniki. Zeszyty Naukowe Instytutu Statystyki i Demografii SGH, 4, pp. 1-28.

Wiktorzak, A.A. (2009). Kapitał społeczny szkoły. In: B. Niemierko, M.K. Szmigel (eds.) Badania międzynarodowe $i$ wzory zagraniczne $w$ diagnostyce edukacyjnej: XV Krajowa Konferencja Diagnostyki Edukacyjnej, Kielce, 4-6 grudnia 2009 r. (pp. 255-262). Kielce: Grupa Tomami. 
Zamkowska, A. (2009). Wsparcie edukacyjne uczniów z upośledzeniem umysłowym w stopniu lekkim w różnych formach ksztatcenia na I etapie edukacji. Radom: Wydawnictwo Politechniki Radomskiej.

Żytko, M. (2015). W jaki sposób ideę „,szkoły współpracy” można włączyć do programu kształcenia nauczycieli? referat wygłoszony na konferencji podsumowującej Projekt Szkoła Współpracy, 15.06.2015 r., Warszawa, Retrived July 12, 2018 from: http://szkolawspolpracy.pl/2015/attachments/article/13/Wyst $\%$ C4\%85pienie_dr\%20hab.\%20Ma\%C5\%82gorzata $\% 20 \%$ C $5 \%$ BBytko.pdf. 